\title{
"PEARL TEA" INOVASI TEH HERBAL BUAH MANGROVE PEDADA (Sonneratia caseolaris) SEBAGAI SUMBER ANTIOKSIDAN DALAM MENDUKUNG TERCAPAINYA INDUSTRI KREATIF 4.0 DAERAH JAMBI \\ "Pearl Tea" Innovation of Herbal Tea Fruit Mangrove Pedada (Sonneratia Caseolaris) As Antioxoxant Source in Supporting The Creation of Creative Industry 4.0 in Jambi Region
}

\author{
Soni Afriansyah" ${ }^{1}$, Bisma Sindi Tira ${ }^{2}$, Ayu Nur Khasanah ${ }^{3}$ \\ ${ }^{1,3}$ Mahasiswa FKIP Universitas Jambi ${ }^{2}$ Mahasiswa FST Universitas Jambi \\ Email :soniafriansyahvevo@gmail.com
}

Diterima: 05 November 2019; di revisi: 19 November 2019 Disetujui : 09 Desember 2019 https://doi.org/10.37250/newkiki.v3i2.43

\begin{abstract}
Mangrove plants that are often found in the East Tanjung Jabung area, one of which is a pedada type mangrove (Sonneratia caseolaris).The content of vitamins A, B1, B2 and C contained in pedada fruit plays an important role in the body's metabolism. The sour taste of the pedada makes people rarely consume the fruit directly. Generally the fruit is processed into food by the surrounding community. However, the lack of public knowledge of the nutritional content of pedada results in the fruit not being utilized optimally. that processing of pedada fruit into the herbal is a good innovation used to support industry 4.0. The purpose of writing this scientific paper is to find out the method of making PEARL TEA, for information about the benefits of consuming PEARL TEA, Analyzing the development and marketing strategies of PEARL Tea. The research method used by collecting data from the literature, data processing, so that it raises the framework of thinking. PEARL TEA is processed using 3 stages, namely preparation, drying, packaging and marketing. Benefits obtained by consuming PEARL TEA include eliminating internal heat, improving brain function, controlling blood sugar, lowering cholesterol, warming the body, preventing blood clots, can detoxify toxins in the body, lose weight, and others. The strategy for developing PEARL TEA is done offline and online. Online marketing is done by utilizing social media as a marketing tool. In the product sales system, PEARL TEA is given a taste and packaging variant as attractive as possible to attract buyers.
\end{abstract}

Keywords: Pedada Fruit, Pearl Tea, Antioxidants and Industry 4.0

\begin{abstract}
Abstrak
Tumbuhan mangrove yang sering ditemukan di daerah Tanjung Jabung Timur, salah satunya adalah jenis mangrove pedada (Sonneratia caseolaris). Kandungan vitamin A, B1, B2 dan C yang terkandung dalam buah pedada memegang peranan penting dalam metabolisme tubuh. Rasa pedada yang masam membuat orang jarang mengkonsumsi buah secara langsung. Umumnya buah ini diolah menjadi makanan oleh masyarakat sekitar. Namun, kurangnya pengetahuan publik tentang kandungan gizi pedada menyebabkan buah tidak dimanfaatkan secara optimal. bahwa pengolahan buah pedada menjadi herbal adalah inovasi yang baik digunakan untuk mendukung industri 4.0. Tujuan penulisan makalah ilmiah ini adalah untuk mengetahui metode pembuatan PEARL TEA, untuk informasi tentang manfaat mengonsumsi TEAR PEARL, Menganalisis pengembangan dan strategi pemasaran PEARL Tea. Metode penelitian digunakan dengan mengumpulkan data dari literatur, analisis data, sehingga menimbulkan kerangka berpikir. PEARL TEA diolah menggunakan 3 tahap, yaitu persiapan, pengeringan, pengemasan dan pemasaran. Manfaat yang diperoleh dengan mengkonsumsi TEH MUTIARA termasuk menghilangkan panas dalam, memperbaiki fungsi otak, mengontrol gula darah, menurunkan kolesterol, menghangatkan tubuh, mencegah pembekuan darah, dapat mendetoksifikasi racun dalam tubuh, menurunkan berat badan, dan lain-lain. Strategi untuk mengembangkan TEAR PEARL dilakukan secara offline dan online. Pemasaran online dilakukan dengan memanfaatkan media sosial sebagai alat pemasaran. Dalam sistem penjualan produk, PEARL TEA diberikan varian rasa dan kemasan semenarik mungkin untuk menarik pembeli.
\end{abstract}

Kata kunci : Buah Pedada, Pearl Tea, Antioksidan dan Industri 4.0

PENDAHULUAN

Mangrove merupakan komunitas tanaman air payau yang banyak dijumpai di
Indonesia. Ekosistem mangrove di Indonesia mencapai $75 \%$ dari total mangrove di Asia Tenggara atau sekitar 
$27 \%$ dari luas mangrove di dunia (Wiratno et al., 2017). Luas hutan mangrove di Indonesia antara 2,5 hingga 4,5 juta hektar, merupakan mangrove terluas di dunia (Rahman et al., 2016). Salah satu Provinsi yang memiliki ekosistem hutan mangrove terluas di Pulau Sumatera adalah Jambi. Luas hutan mangrove di Jambi mencapai 65.000 hektar dengan potensi mangrove terbanyak berada di Kabupaten Tanjung Jabung Timur yaitu total luas lahan adalah 4.126,6 hektar.

Tanaman mangrove yang banyak dijumpai di Daerah Tanjung Jabung Timur salah satunya adalah mangrove jenis pedada (Sonneratia caseolaris). Rasa asam (Ph 3,11-4,23) (Rahman,2016), yang dimiliki buah pedada membuat masyarakat jarang mengkonsumsi buah tersebut secara langsung. Umumnya buah diolah menjadi pangan oleh masyarakat sekitar. Namun, minimnya pengetahuan masyarakat terhadap kandungan gizi buah pedada menyebabkan buah tersebut tidak dimanfaatkan dengan optimal.

Keberadaan buah mangrove yang melimpah memudahkan masyarakat pesisir untuk mendapatkannya tanpa harus mengeluarkan biaya banyak. Namun, pemanfaatan tanaman mangrove sebagai sumber pangan masih sangat terbatas. Menurut Wiratno et al., (2017) buah pedada memiliki kandungan fitokimia seperti protein $2,21 \%$, abu $1,42 \%$, lemak $1,83 \%$ dan karbojidrat 2,24\%, vitamin C dalam 100 gram sebanyakk 56,74 mg, vitamin B1 5,04 mg dan kadar air 1,63$1,70 \%$. Senyawa fitokimia seperti flavonoid merupakan antioksidan yang menetralisir radikal bebas yang menyerang sel-sel tubuh kita, radikal bebas tersebut dapat menyebabkan kanker, penyakit jantung dan penuaan dini (Ahmad,2010). Pengetahuan akan manfaat buah pedada dan keterampilan dalam pengolahannya perlu ditingkatkan agar pemanfaatannya pun lebih optimal.

Salah satu pemanfaatan buah pedada yaitu berupa teh herbal yang disukai dan biasa dikonsumsi sehari-hari oleh masyarakat. Buah pedada memiliki kandungan air yang cukup tinggi, sehingga pengolahannya sebagai teh herbal harus melalui proses pengeringan yang mengakibatkan kadar air berkurang sehingga dapat memperpanjang massa simpan dan mempermudah penggunaannya. Pengeringan dilakukan dengan menggunakan oven suhu $50^{\circ} \mathrm{C}$ selama 18 jam.

Produk olahan mangrove memiliki prospek yang menggiurkan jika diproduksi sesuai standar mutu serta didukung oleh promosi yang menarik. Metode yang 
digunakan pada penelitian ini yaitu preparasi, pengeringan, pengemasan dan pemasaran. Pada proses pengemasannya, buah pedada yang telah dipreparasi dilakukan penambahan serbuk kulit kayu manis dan serbuk kunyit, yang bertujuan untuk memberikan rasa dan aroma teh yang khas dan nikmat. Produk ini diberi nama PEARL TEA (Pedada Herbal Tea), dengan komposisi buah pedada $60 \%$, kulit kayu manis 20\% dan kunyi 20\%t akan memberikan banyak manfaat salah satunya mencegah penyakit yang disebabkan oleh radikal bebas seperti kanker, jantung, dan penuaan dini. Hal ini disebabkan ketiga bahan herbal dalam PEARL TEA memiliki kandungan antioksidan yang dapat menstablikan radikal bebas.

Produksi PEARL TEA tentunya akan memberikan dampak yang cukup baik, tidak hanya bagi kesehatan namun juga dapat meningkatkaan ekonomi masyarakat pesisir Tanjung Jabung Timur. Diharapkan PEARL TEA dapat menjadi salah satu teh herbal yang digemari masyarakat dan mampu bersaing dengan teh lainnya di pasaran.

Berdasarkan latar belakang yang telah dipaparkan, Diperoleh beberapa rumusan masalah sebagai berikut :

1. Bagaimana metode pembuatan PEARL TEA?
2. Apa manfaat yang dapat diperoleh dari mengkonsumsi PEARL TEA?

3. Bagaimana strategi pengembangan dan pengembangan PEARL TEA?

Adapun tujuan dari penulisan karya ilmiah ini adalah sebagai berikut :

1. Mengetahui metode pembuatan PEARL TEA.

2. Memperoleh informasi mengenai manfaat dari mengkonsumsi PEARL TEA.

3. Menganalisa strategi pengembangan dan pemasaran PEARL TIEA.

\section{TINJAUAN PUSTAKA}

Ekosistem Mangrove Tanjung Jabung Timur

Karakteristik Ekosistem Mangrove Pantai Timur Jambi merupakan habitat utama kawasan pesisir Tanjung Jabung Timur sebagaimana kawasan pesisir Sumatera bagian timur berupa vegetasi hutan mangrove. Ekosistem mangrove yang ada di sepanjang kawasan pesisir pantai Kabupaten Tanjung Jabung Timur selalu tergenang air walaupun pada saat air surut. Vegetasi yang dominan yang terdapat di pantai timur Jambi adalah jenis Api-api atau Bakau hitam (Avicennia sp.), Bakau merah (Rhizophora sp.), Pidada (Sonneratia sp.) dan Tanjang (Bruguiera sp.). Disepanjang pantai diduduki oleh jenis Pidada 
(Sonneratia sp.), kemudian pada daerah dengan genangan pasang agak rendah diduduki oleh jenis Api-api dan Tanjang, selanjutnya pada kedalaman pasang tertinggi diduduki oleh jenis tumbuhan bakau serta pada sisi kanan dan sisi kiri sungai. Disepanjang sungai dan tempattempat tertentu dipantai ditumbuhi oleh jenis nipah yang diselingi oleh pedada dan bakau.

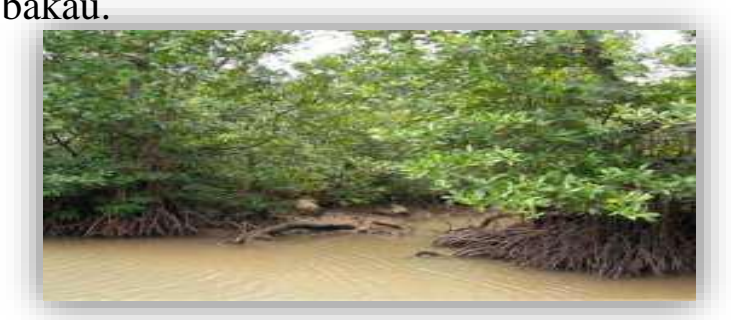

Gambar 1.

Ekosistem mangrove di Tanjabtim

\section{Pedada (Sonneratiacaseolaris)}

Pedada (Sonneratia caseolaris) merupakan salah satu penyusun hutan bakau yang berada di sepanjang pantai berlumpur yang mempunyai salinitas rendah dan merupakan wadah berkumpulnya kunang-kunang. Klasifikasi pedada menurut Tomlinson (1986) diacu dalam Kusmana et al. (2008) adalah sebagai berikut :

Kingdom : Plantae

Filum : Anthophyta

Kelas : Angiospermae

Ordo : Myrtales

Family : Sonneraticeae

Genus : : Sonneratia

Spesies : Sonneratia caseolaris

Bentuk buah pedada dapat dilihat pada Gambar 2, berbentuk bulat, ujung bertangkai, dan bagian dasarnya terbungkus kelopak bunga. Buah ini memiliki diameter antara 6-8 $\mathrm{cm}$ dan biji berjumlah antara 800-1200. Menurut Chen et al. (2009) tentang dinamika dan struktur hutan mangrove, bahwa buah pedada berwarna hijau, dan mempunyai aroma yang sedap. Selain itu, buah pedada tidak beracun, memiliki rasa asam dan dapat langsung dimakan. Pernyataan ini diperkuat oleh Setiawan (2016), buah pedada yang matang penuh dicirikan dengan berwarna hijau kekuning-kuningan dengan tekstur yang lunak dan buah sudah jatuh.

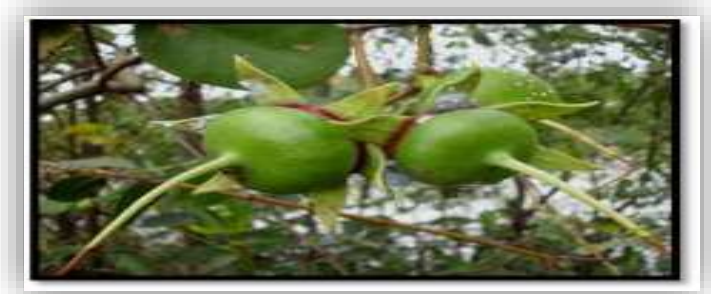

Gambar 2. Buah Pedada

Buah pedada memiliki 24 komponen termasuk delapan steroid, sembilan triterpenoid, tiga flavonoid, dan empat turunan karboksil benzena. Menurut Peteros dan Uy (2010) tentang triterpenoid, steroid, flavonoid dan turunan karboksil benzena yang terdapat pada ekstrak tanaman dan buah berfungsi sebagai antiinflamasi, analgesik, antioksidan, antialergi, antijamur, antimikroba, dan lainnya. Triterpenoid juga dapat berfungsi pada pencegahan dan pengobatan hepatitis. 
Flavonoid yang terdapat pada ekstrak tanaman juga dapat digunakan dalam pengobatan rematik (Varghese,2010).

Daging buah pedada mengandung saponin dan steroid yang memiliki aktivitas sebagai analgesik dan anti inflamasi. Selain itu, buah pedada juga mengandung vitamin A, B1, B2, dan C yang berperan dalam metabolisme tubuh terutama produksi energi dan sintesis protein. Dengan kandungan vitamin yang begitu banyak pada buah pedada kebanyakan masyarakat mengolahnya menjadi selai pedada dan sirup pedada (Bandarayanake,2002). Namun, belum ada yang memanfaatkan pedada menjadi teh herbal, mengingat kandungannya yang cukup banyak. Kandungan gizi buah pedada disajikan pada tabel 1 .

Tabel 1. Kandungan gizi buah pedada

\begin{tabular}{|l|c|}
\hline Komponen (Basis kering) & Buah pedada \\
\hline Aktivitas vitamin A (RE) & 11,21 \\
\hline Vitamin B1 (mg/100 g) & 5,04 \\
\hline Vitamin B2 (mg/100 g) & 7,65 \\
\hline Vitamin C (mg/100 g) & 56,74 \\
\hline
\end{tabular}

Sumber : Manalu RDE, et al.(2013).

\section{Kunyit (Curcuma domestica)}

Kunyit adalah salah satu jenis rempah-rempah yang banyak digunakan sebagai bumbu dalam berbagai jenis masakan. Kunyit memiliki nama latin Curcuma domestica. Kunyit termasuk salah satu suku tanaman temu-temuan (Zingiberaceae). Menurut Winarto (2004),

dalam taksonomi tanaman kunyit dikelompokkan sebagai berikut :
Kingdom : Plantae
Divisio : Spermatophyta
Class : Monocotyledonae
Ordo : Zingiberales
Family : Zingiberaceae
Genus : Curcuma
Species : Curcuma domestica

Tanaman kunyit tumbuh bercabang dengan tinggi 40-100 cm. Batang merupakan batang semu, tegak, bulat, membentuk rimpang dengan warna kekuningan dan tersusun dari pelepah daun (agak lunak). Daun tunggal, bentuk bulat telur (lanset) memanjang hingga 10-40 cm, lebar 8-12,5 $\mathrm{cm}$ dan pertulangan menyirip dengan warna hijau pucat.

Kusbiantoro dan Purwaningrum (2018), menyatakan bahwa kunyit merupakan tanaman obat dan bumbu masakan yang banyak digunakan oleh sebagian besar masyarakat di Indonesia dan India.

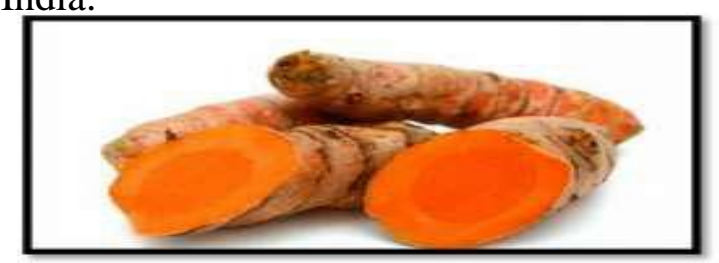

Gambar 3. Kunyit

Kunyit mengandung senyawa yang berkhasiat obat, yang disebut kurkuminoid yang terdiri dari kurkumin, desmetoksikumin dan bisdesmetoksikurkumin serta zat-zat manfaat lainnya. Rimpang kunyit mengandung $28 \%$ glukosa, $12 \%$ fruktosa, $8 \%$ protein, dan 
kandungan kalium dalam rimpang kunyit cukup tinggi, 1,3-5,5\% minyak atsiri yang terdiri $60 \%$ keton seskuiterpen, 25\% zingiberina dan 25\% kurkumin berserta turunannya (Winarti dan Nurdjanah, 2005).

Tabel 2. Kandungan senyawa pada kunyit

\begin{tabular}{|l|l|}
\hline Kandungan & Jumlah dalam 100 g \\
\hline Energi & $390,00 \mathrm{Kcal}$ \\
\hline Kalsium & $20,00 \mathrm{mg}$ \\
\hline Karbohidrat & $6990,00 \mathrm{mg}$ \\
\hline Lemak & $890,00 \mathrm{mg}$ \\
\hline Asam askorbat & $50,00 \mathrm{mg}$ \\
\hline Zat besi & $4750,00 \mathrm{mg}$ \\
\hline Niasin & $4,80 \mathrm{mg}$ \\
\hline Kalium & $200,00 \mathrm{mg}$ \\
\hline Fosfor & $260,00 \mathrm{mg}$ \\
\hline Protein & $850,00 \mathrm{mg}$ \\
\hline Riboflavin & $0,19 \mathrm{mg}$ \\
\hline Natrium & $30,00 \mathrm{mg}$ \\
\hline Tiamin & $0,09 \mathrm{mg}$ \\
\hline Air & $60,00 \mathrm{mg}$ \\
\hline
\end{tabular}

Kayu Manis (Cinnamomum burmanni)

Kayu manis adalah rempah-rempah yang terdapat di Indonesia dan memiliki banyak manfaat, khususnya di Propinsi Jambi. Kayu manis termasuk salah satu dari lima komoditi unggulan selain karet, kelapa sawit, kelapa dan kopi. Ekstrak kulit kayu manis dapat digunakan sebagai antidiabet dan antioksidan. Minuman dengan penambahan kayu manis berpotensi untuk dikembangkan sebagai minuman fungsional untuk menurunkan kadar glukosa darah pada penderita gula darah tinggi (Yulia,2015). Berdasarkan percobaan yang dilakukan oleh Hastuti (2014), Penambahan kayu manis menaikkan $\mathrm{pH}$ minumaan fungsional.
Semakin banyak kayu manis menaikkan $\mathrm{pH}$ minuman funsgional. Dengan semakin banyak penambahan kayu manis, warna minuman yang dihasilkan semakin gelap. Adapun klasifikasi tanaman kulit kayu manis adalah sebagai berikut :

Kingdom : Plantae

Divisi : Magnoliophyta

Kelas : Magnoliopsida

ordo : Laurales

famili : Lauraseae

genus : Cinnamomum

spesies : Cinnamomum burmanni

Kulit kayu manis memiliki bau.

khas aromatik, rasa agak manis, agak pedas,dan kelat. Pada pengamatan secara makroskopik, potongan kulit berbentuk gelondong agak menggulung membujur, agak pipih, atau berupa berkas yang terdiri tumpukan beberapa potong kulit yang tergulung membujur panjang sampai $1 \mathrm{~m}$, tebal kulit $1 \mathrm{~nm}$ sampai $3 \mathrm{~nm}$ atau lebih

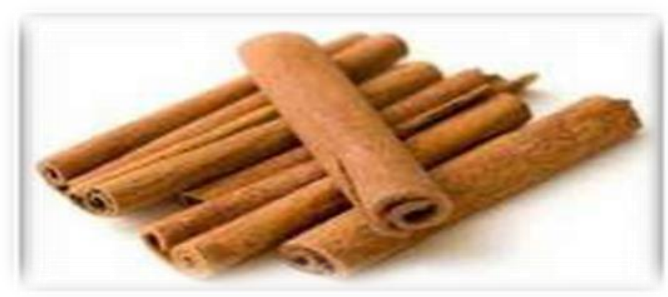

Gambar 4. Kayu manis

Kayu manis termasuk salah satu bahan makanan sumber antioksidan. Aktivitas antioksidan kayu manis yang diperoleh melalui ekstraksi menggunakan aquades sebesar 45,42\% (Hastuti, 2014). Minyak atsiri yang berasal dari kulit komponen terbesarnya ialah sinamaldehida 
60-70\% ditambah dengan eugenol, Beberapa jenis aldehida, benzylbenzoat, phelandrene dan lain-lainnya. Kadar eugenol rata-rata 80-90\%. Dalam kulit masih banyak komponen-komponen kimiawi misalnya: damar, pelekat, tanin, zat penyamak, gula, kalsium, oksalat, dua jenis insektisida cinnzelanin dan cinnzelanol, cumarin dan sebagainya (Rimunandar, 2001).

Kulit kayu manis mempunyai rasa pedas dan manis, berbau wangi, serta bersifat hangat. Beberapa bahan kimia yang terkandung di dalam kayu manis diantaranya minyak atsiri eugenol, safrole, sinamaldehide, tannin, kalsium oksalat, damar dan zat penyamak (Hariana, 2007).

\section{Teh Herbal}

Teh merupakan minuman yang sudah dikenal secara luas di Indonesia dan di Dunia. Minuman ini umum menjadi penjamu tamu. Aroma dan rasanya yang khas membuat minuman ini banyak dikonsumsi. Selain itu karena zat-zat yang terkandung dalam teh memiliki banyak manfaat bagi kesehatan (Jimmy, 2010). Menurut Soraya (2007), teh memiliki banyak manfaat yang berguna bagi kesehatan tubuh sebagai antioksidan, memperbaiki sel-sel yang rusak, menghaluskan kulit, melangsingkan tubuh,mencegah kanker, mencegah penyakit jantung, mengurangi kolesterol dalam darah dan melancarkan sirkulasi darah.

Teh herbal merupakan teh yang tidak hanya berasal dari tanaman daun teh yaitu Camelia sinensis. Teh herbal dapat dikonsumsi sebagai minuman sehat yang praktis tanpa mengganggu rutinitas seharihari dan tetap menjaga kesehatan tubuh. Teh herbal yang dibuat diharapkan dapat meningkatkan cita rasa dari tiap bahan yang digunakan tanpa mengurangi khasiatnya (Verna dan Alpana, 2014).

Tabel 3. Syarat mutu teh kering dalam kemasan Menurut SNI 3836:2013

\begin{tabular}{|c|c|c|c|}
\hline no & Kriteria uji & Satuan & Persyaratan \\
\hline 1. & Keadaan air seduhan & & \\
\hline 2. & Warna & - & Khas produk the \\
\hline 3 & Bau & - & Khas produk the \\
\hline 4 & Rasa & - & Khas produk the \\
\hline 5 & Kadar polifenol (b/b) & $\%$ & $\mathrm{M}$ in 52 \\
\hline 6 & Kadar air (b/b) & $\%$ & Maks 8,0 \\
\hline 7 & Kadar ekstrak dalam air (b/b) & $\%$ & $\mathrm{M}$ in 32 \\
\hline 8 & Kadar abu total (b/b) & $\%$ & Maks 8,0 \\
\hline 9 & Kadar abu larut dalam air & $\%$ & $\mathrm{M}$ in 45 \\
\hline 10 & dari abu total $(\mathrm{b} / \mathrm{b})$ & & \\
\hline 11 & Kadar abu tak larut dalam & $\%$ & Maks 1,0 \\
\hline 12 & asam $(b / b)$ & & \\
\hline 13 & Alkalinitas abu larut dalam & $\%$ & $1-3$ \\
\hline 14 & air (sebagai $\mathrm{KOH}$ ) b/b & & \\
\hline 15 & Serat kasar & $\%$ & Maks 16,5 \\
\hline
\end{tabular}

(Komes, 2010). 


\section{METODE PENELITIAN}

\section{Pengumpulan Data}

Teknik pengumpulan berupa data kualitatif, Pada penelitian ini data yang digunakan dalam memperkuat gagasan yang penulis tuangkan dalam karya tulis ini yaitu dengan cara studi pustaka, dimana berdasarkan rumusan masalah yang dibahas pada bagian pendahuluan, maka penulis berusaha mencari sumber pustaka dari internet, buku, maupun jurnal-jurnal penelitian yang relevan minimal 5 tahun terakhir, mempelajarinya, dan menuangkannya dalam tinjauan pustaka.

\section{Analisis Data}

Karya tulis ini disusun berdasarkan format penulisan karya tulis ilmiah dengan menggunakan bahasa indonesia yang baik dan benar. Langkah-langkah pengolahan data yang dilakukan yaitu dengan cara sintesis, dalam hal ini penulis mencari data berdasarkan jurnal-jurnal penelitian yang relevan dengan rumusan masalah yang diangkat. Berdasarkan jurnal dan pengamatan awal peneliti mengenai buah pedada ternyata buah tersebut dapat diolah menjadi sebuah produk. Data yang telah didapatkan ini kemudian dijabarkan secara deskriptif kualitatif baik dalam bentuk data tulisan maupun gambar.

\section{Kerangka Berpikir}

Karya tulis ini mengangkat masalah mengenai pemanfaatan buah Pedada (Sonneratia caseolaris) yang selama ini belum terlalu dioptimalkan oleh masyarakat TANJABTIM, dengan menggagas inovasi produk pangan alternatif berupa teh herbal buah pedada yang dicampur dengan kunyit dan kayu manis yang diberi nama PEARL TEA (Pedada Herbal Tea). Proses produksi PEARL TEA melalui beberapa tahapan yaitu preparasi, pengeringan, pengemasan, dan pemasaran. Dalam proses promosi produk, penulis berupaya membuat packaging sedemikian rupa untuk menarik minat pembeli.

\section{HASIL DAN PEMABAHASAN}

\section{Buah Pedada}

Buah Pedada dapat dengan mudah ditemukan di Indonesia. Menurut Giri et al (2011 di Pusat Penelitian Kehutanan Internasional, 2015), sekitar 3 juta hektar hutan bakau tumbuh sepanjang 95.000 kilometer Pesisir Indonesia. Ini mewakili 23 persen dari total ekosistem bakau dunia. Salah satunya di Provinsi Jambi dengan total luas 3.989,3 hektare. Tanjung Jabung Barat, salah satu kabupaten di Jambi, adalah hutan bakau terbesar yang tumbuh 
di Jambi dengan 689,8 hektar tumbuh di Kabupaten Tanjung Labu (Kuala Tungkal); 752,5 hektar berada di Pangkal Babu Betara Kanan; 594,3 hektar adalah Sungai Dualap; 835,2 hektar lainnya menumbuhkan Tungkal HarapanPembengis; 659,4 hektar berada di Left Bram Itam; dan 467,1 hektar tumbuh di Desa Bukal IV(Soni,2018).

Daging buah pedada memiliki kandungan gizi yang tinggi. Kandungan gizi per $100 \mathrm{gr}$ daging buah pedada terdapat vitamin A 221,97 IU, vitamin B 5,04 mg, vitamin B2 7,65 mg dan vitamin C 56,7 mg (Rahman, 2016). Buah pedada memiliki rasa asam dan aroma yang sangat khas, sehingga menjadi daya tarik buah tersebut. Buah pedada tidak beracun dan dapat dikonsumsi secara langsung, namun karena rasanya yang asam membuat masyarakat jarang mengkonsumsi buah tersebut secara langsung.

Pemanfaatan buah pedada sampai saat ini belum maksimal dan popular di masyarakat. Hal ini disebabkan masih minimnya pengetahuan masyarakat terhadap buah pedada dan rasa asam pada buah yang menyebabkan masyarakat cenderung kurang menyukainya (Wiratno,2017). Buah pedada memiliki kandungan fitokimia seperti steroid, triterpenoid dan flavonoid. Senyawa fitokimia seperti flavonoid merupakan antioksidan yang dapat menetralisir radikal bebas yang menyerang sel-sel tubuh kita, radikal bebas tersebut dapat menyebabkan kanker, penyakit jantung dan penuaan dini (Ahmed, 2010).

Buah pedada sudah pernah diolah menjadi selai, sirup, dodol (Rudianto, 2015), dan fruit leather (Rahman, 2016). Ekstrak buah pedada secara tradisional juga sudah digunakan sebagai antiseptik, mengobati keseleo dan mencegah pendarahan. Salah satu upaya pemanfaatan buah pedada yang lain yaitu mengolahnya menjadi teh herbal (Minqing,2009). Pengolahan buah pedada sebagai teh merupakan produk yang memiliki daya simpan yang lama karena kadar airnya yang rendah 1,63-1,70\% sehingga mutu produk lebih terjaga dan tidak mudah kotor serta terhindar dari mikroba pembusuk. Produk pangan tersebut juga mudah ditangani dan praktis dalam penyajiannya (Angria,2011).

\section{PEARL TEA (Pedada Herbal Tea)}

Pengeringan dapat dilakukan dengan bantuan sinar matahari dan alat pengering. Suhu pengeringan herbal yang baik adalah berkisar antara $30-90^{\circ} \mathrm{C}$ tetapi suhu terbaik untuk pengeringan menurut Depkes RI (1995) sebaiknya tidak melebihi $60^{\circ} \mathrm{C}$. Buah pedada 100 gr yang telah 
dikumpulkan dan dibersihkan diiris tipistipis (1-5 mm). Selanjutnya diletakkan kedalam loyang dan dikeringkan pada oven $50^{\circ} \mathrm{C}$ selama 18 jam.

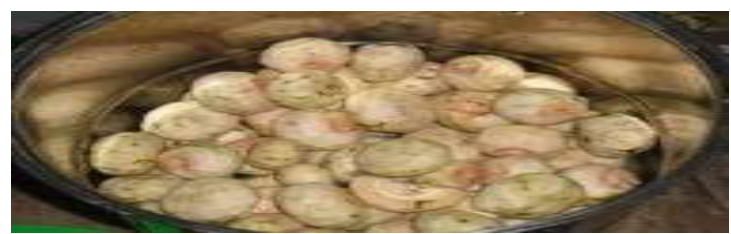

Gambar 5.

Buah pedada yang sudah dikupas

Pengeringan merupakan suatu cara untuk mengeluarkan atau menghilangkan sebagian air dari suatu bahan dengan menguapkan sebagian besar air yang dikandung melalui penggunaan energi panas.

Pengeringan dapat berlangsung dengan baik jika pemanasan terjadi pada setiap tempat dari bahan tersebut, dan uap air yang diambil berasal dari semua permukaan bahan tersebut. Prinsip proses pengeringan adalah proses terjadinya pindah panas dan difusi air dari bahan yang dikeringkan. Pindah panas tersebut memerlukan fase air dari air menjadi uap. Selama pengeringan bahan akan kehilangan kadar air, sehingga naiknya kadar zat gizi didalam masa yang tertinggal. Jumlah protein, lemak, dan karbohidrat yang ada per satuan berat didalam bahan pangan kering lebih besar dari pada didalam bahan pangan segar (Hamsah, 2013).
Bahan lain yang digunakan dalam pembuatan PEARL TEA adalah kayu manis. Kayu manis yang digunakan sebagai bahan tambahan ini dipreparasi dengan cara dibersihkan terlebih dahulu, setelah diangin-anginkan selanjutnya dicacah dan dikeringkan pada oven suhu $50^{\circ} \mathrm{C}$. kayu manis yang sudah kering selanjutnya dihaluskan dadiayak agar memiliki luas permukaan yang sama. Begitupula dengan preparasi jahe, yaitu dicuci, dikeringkan, dihaluskan dan diayak. Setelah semua bahan telah dipreparasi selanjutnya disatukan dengan perbandingan kayu manis dan jahe sebesar $(4 \%$ dan $3 \% \mathrm{~g} / \mathrm{g}$ berat

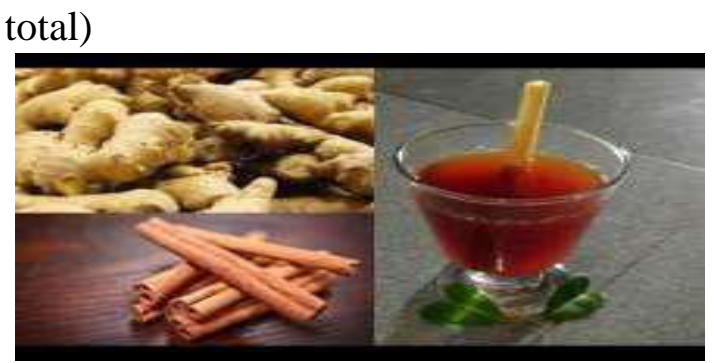

\section{Gambar 6. Tea Herbal}

\section{Manfaat PEARL TEA}

PEARL TEA memiliki beberapa komposisi bahan herbal berupa buah pedada, kunyit, dan kayu manis dengan komposisi masing-masing (60\% : 20\% :20 $\%)$ Ketiga bahan tersebut memiliki kandungan yang sangat berpotensi untuk menyehatkan dan mencegah penyakit menyerang tubuh manusia.

Kunyit sebagai antioksidan berperan memberikan aroma yang khas pada 
makanan dan memberikan sifat-sifat ketahanan dan pengawetan. Kunyit sebagai antoksidan berperan untuk menghambat petumbuhan dan aktivitas mikroba. Komponen utama pigmen kunyit yang bersifat antioksidan dan antitoksin adalah kurkumin. Selain itu kurkumin dan minyak atsiri berfungsi menguatkan lambung dan menurunkan kolesterol (Hartati, 2015).

Selanjutnya kayu manis memiliki banyak manfaat bagi kesehatan. Beberapa manfaat kayu manis diantaranya (Sulistyani, 2013) :

1. Terbukti dapat menurunkan atau mengontrol kadar gula pada penderita diabetes

2. Kayu manis dapat menurunkan kolesterol jahat dan trigliserida atau asam lemak di dalam darah

3. Memiliki sifat anti jamur dan anti bakteri

4. Bubuk kayu manis dapat juga digunakan sebagai alternative untuk pengawet makanan, hal ini disebabkan karena sifat anti mikroba yang kuat.

5. Aroma kayu manis akan meningkatkan funsi otak, meningkatkan daya ingat dan kinerja otak.

Berdasarkan uraian diatas diketahui bahwa ketiga jenis bahan herbal tersebut angat kaya akan kandungan antioksidan. Antioksidan merupakan penstabil radikal bebas yang bekerja dengan cara melengkapi kekurangan electron radikal bebas dan menghambat terjadinya reaksi berantai dari pembentukan radikal bebas. Upaya untuk meningkatkan pertahanan untuk antioksidan guna menghambat peningkatan stress oksidatif dapat dilakukan dengan cara meningkatkan antioksidan dari luar tubuh (Hastuti, 2014). Kayu manis merupakan bahan makanan sumber antioksidan. Aktivitas antioksidan kayu manis yang diperoleh melalui ekstraksi menggunakan aquades sebesar $45,42 \%$. Senyawa fitokimia ini menjadikan kayu manis potensial sebagai antiioksidan. Wiratno et al. (2017) menyatakan bahwa radikal bebas dapat menyebakan kanker, penyakit jantung,dan penuaan dini.

\section{Peranan PEARL TEA dalam kesehatan}

Kesehatan dan kesejahteraan termasuk dalam goal ke-3 pada pilar pembangunan sosial diprioritas target SDGs di Indonesia. Sektor kesehatan pada SDGs terdapat 4 goal, diantaranya yaitu gizi masyarakat, sistem kesehatan nasional, akses kespro, KB serta sanitasi dan air bersih. Goals sistem kesehatan nasional memiliki 13 target, yang menjamin kehidupan yang sehat dan mendorong kesejahteraan bagi semua orang disegala usia. Diantara 13 target tersebut, salah satunya yaitu bertujuan mengurangi secara 
substansial kematian dan kesakitan akibat senyawa berbahaya serta kontaminasi dan polusi udara, air dan tanah (Agus Sutopo, dkk: 2014). Berdasarkan hasil rikerdas (2007), untuk kematian akibat stroke mencapai $15,4 \%$. Target 2025 pada penerapan SDGs yaitu menurunkan sebesar $25 \%$ semua kematian akibat kanker, diabetes, atau penyakit respirasi kronis.

Sel secara rutin menghasilkan radikal bebas dan kelompok oksigen reaktif yang merupakan bagian dari proses metabolisme. Pada saat produksi radikal bebas melebihi antioksidan pertahanan seluler maka dapat terjadi stress oksidatif (Sinaga, 2016). Stress oksidatif adalah kondisi ketidakseimbangan antara jumlah radikal bebas yang ada dengan jumlah antioksidan didalam tubuh. Stress oksidatif berperan penting dalam patofisiologi terjadinya proses menua dan berbagai penyakit degenaritif, seperti kanker, diabetes melitus dan komplikasinya, serta aterosklrosis yang mendasari penyakit jantung, pembuluh darah dan stroke (Werdhasari,2014).

Radikal bebas adalah atom atau molekul yang mempunyai elektron yang tidak berpasangan pada orbital. Dalam rangka mendapatkan stabilitas kimia, radikal bebas tidak dapat mempertahankan bentuk asli dalam waktu lama dan segera berikatan dengan bahan sekitarnya. Radikal bebas akan menyerang molekul stabil yang terdekat dan mengambil electron. Zat yang terambil elektronnya akan menjadi radikal bebas juga sehingga akan memulai suatu reaksi berantai, yang akhirnya terjadi kerusakan sel tersebut (Sinaga, 2016). Menurut Sari (2015), Radikal bebas dapat pula dipeorleh dari luar tubuh (eksogen) yang berasal dari polusi udara, asap kendaraan, asap rokok,berbagai bahan kimia, makanan yang telah hangus (carbonated) dan sinar UV.

Antioksidan atau reduktor berfungsi untuk mencegah terjadinya oksidasi atau menetralkan senyawa yang telah teroksidasi, dengan cara menyumbangkan hidrogen dan atau electron. Didalam tubuh terdapat mekanisme antioksidan atau anti radikal bebas secara endogenik. Dimana radikal bebas yang terbentuk akan dinetralkan oleh elaborasi sistem pertahanan antara antioksidan enzim-enzim seperti katalase, superoksid dismutase, glution peroksidase dan sejumlah antioksidan non enzim termasuk diantaranya vitamin $\mathrm{A}, \mathrm{E}$, dan $\mathrm{C}$, glutationin, ubiquinone dan flavonoid (Sinaga, 2016). Menurut Werdhasari (2014), Antioksidan sangat diperlukan oleh tubuh untuk mengatasi dan mencegah stress oksidatif. Berbagai bahan alam di 
Indonesia banyak mengandung antioksidan dengan berbagai bahan aktifnya. Penggunaan bahan alam asli Indonesia sebagai antioksidan diperlukan untuk meningkatkan kualitas kesehatan masyarakat dengan biaya relatif terjangkau.

Strategi pengembangan PEARL TEA

\section{Analisis peluang}

Teh merupakan minuman yang sangat akrab dengan masyakat Indonesia, teh dapat dinikmati saat makan, menjamu tamu, ataupun saat santai, karena teh dapat merilekskan tubuh dan pikiran sehingga minuman ini sering dikonsumsi oleh masyarakat. Umumnya, teh yang dipasarkan berupa teh hijau, teh hitam, ataupun lainnya. Sedangkan untuk teh herbal masih belum banyak diproduksi secara luas, khususnya teh herbal mangrove dari buah pedada atau PEARL TEA. Sehingga kehadiran PEARL TEA sebagai produk baru teh herbal buah mangrove memiliki peluang yang cukup besar, karena belum ada produk sejenis lainnya yang memproduksi teh herbal dari buah manrove pedada. Sehingga konsumen yang pada dasarnya memiliki rasa penasaran dengan hal baru akan tertarik untuk mencoba PEARL TEA.

\section{Segmentasi dan target pasar}

Dalam merancang pemasaran perlu adanya segmentasi dan target pasar domestik, diharapkan PEARL TEA dapat dinikmati oleh setiap kalangan karena tidak menggunakan bahan yang berbahaya. Selain itu harga PEARL TEA yang bersahabat dan ramah dikantong akan lebih mudah untuk masuk ke masyarakat kalangan menengah kebawah maupun menengah keatas. PEARL TEA dapat dipasarkan sebagai produk khas jambi.

\section{Strategi Promosi}

Strategi penjualan yang dilakukan ialah secara online dan offline. Promosi online dilakukan dengan memanfaatkan berbagai macam media sosial seperti facebook, instagram, line, dan whatsapp. Selain itu PEARL TEA juga akan dipromosikan melalui toko online seperti buka lapak, tokopedia, lazada, dan shopee. Sedangkan promosi offline dilakukan dengan membuka kedai teh yang dapat dinikmati secara langsung oleh konsumen ataupun hanya dibeli sebagai teh keringnya saja. Untuk meningkatkan kepuasan konsumen penulis berencana memberikan varian rasa pada PEARL TEA yang dinikmati secara langsung di kedai maupun dibawa pulang sebagai teh yang sudah diolah. Berdasarkan dari tingginya angka kesukaan khususnya remaja pada teh Thailand atau yang dikenal dengan THAI TEA yang memiliki berbagai macam rasa, 
maka penulis juga akan memberikan opsi kepada konsumen yang ingin membeli teh yang sudah diolah untuk memilih varian rasa yang disuka, sepeti dengan rasa original, milo, red velvet, vanilla dan coklat.

Untuk lebih mengembangkan dan memperkenalkan produk maka promosi offline selain membuka kedai yaitu penulis juga akan berpartner dengan tempat penjualan oleh-oleh khas Jambi, outlet makanan dan minuman maupun warungwarung. Tidak hanya itu, dalam rangka memperluas daerah pemasaran, maka akan digunakan beberapa distributor dan agen untuk memasarkan produk PEARL TEA.

\section{Simpulan}

Adapun kesimpulan yang diperoleh dari karya tulis ini adalah sebegai berikut:

1. PEARL TEA diproses dengan menggunakan 3 tahapan, yaitu preparasi, pengeringan, pengemasan dan pemasaran.

2. Manfaat yang diperoleh dengan mengkonsumsi PEARL TEA diantaranya menghilangkan panas dalam, meningkatkan fungsi otak, mengontrol gula darah, menurunkan kolesterol, menghangatkan tubuh, mencegah penggumpalan darah, dapat mendetoksifikasi racun dalam tubuh, menurunkan berat badan, dan lain lain.

3. Strategi pengembangan PEARL TEA dilakukan secara offline dan online. Pemasaran online dilakukan dengan memanfaatkan media sosial sebagai alat pemasaran. Pada sistem penjualan produk, PEARL TEA diberi varian rasa dan packaging dikemas semenarik mungkin untuk memikat pembeli.

\section{Saran}

Perlu dilakukan kerjasama dengan pihak-pihak tertentu dalam mengembangkan produk ini, salah satunya seperti pengurusan label halal oleh MUI dan nomor BPOM. Selain itu perlu adanya inovasi dalam promosi produk agar PEARL TEA dapat dengan mudah masuk ke pasaran dan dikenal oleh masyarakat luas serta dirasakan manfaatnya. Dan juga Sebaiknya dilakukan penelitian secara langsung untuk mendapatkan data primer dan tidak hanya menggunakan data sekunder.

\section{Daftar Pustaka}

Ahmed, R., S. J. Moustami., H. Ahmed., M. Ali, W.M. Haq, R. Jahan dan M. Rahmatullah. 2010. Serum glucose and lipid profiles in rats following administration of Sonneratia caseolaris (L.)Engl. (Sonneratiaceae) leaf powder in diet. Journal Advance in Natural and 
Applied Science. Volume 4 (2) : 171173.

Angria, M. 2011. Pembuatan minuman instan pegagan (Centella asiatica) dengan citarasa cassia vera. Skripsi. Fakultas Teknologi Pertanian. Universitas Andalas Padang

Bandarayanake. 2002. Bioactivities, bioactive compounds and chemical constituents of mangrove plants. Kluwer Academic Publishers, Ecology of mangrove plant 10(2):421-452.

BSN (Badan Standarisasi Nasional). 2013. Tentang Bahan Tambahan

Makanan. Jakarta: Badan

Standarisasi Nasional

Chen L, Zan Q, Li Mingguang, Shen J, Liao W. 2009. Litter dynamics and forest structure of the introduced Sonneratia caseolaris mangrove forest in Shenzhen, China. Estuarine, Coastal and Shelf Science 85(2):241246.

Departemen Kesehatan Republik Indonesia. 1995. Materia Medika Indonesia Jilid I.Jakarta: Direktorat Pengawasan Obat dan Makanan

Hariana, A. 2007. Tumbuhan Obat dan Khasiatnya. Seri 2. Jakarta : Penebar Swadaya.

Hartati, S. Y dan Balittro. 2015 . Khasiat Kunyit Sebagai Obat Tradisional dan Manfaat Lainnya. Warta Penelitian dan Pengembangan Tanaman Industri. Volume 19 (2): 5-9.

Hastuti, Murdi, A. dan Rustanti, N. 2014. Pengaruh Penambahan Kayu Manisterhadap Aktivitas Antioksidan dan Kadar Gula Minuman Fungsional Secang dan Daun Stevia sebagai Alternatif Minuman bagi Penderita Diabetes Melitus Tipe 2. Journal Noutrition College. 3(3):362-369.
Jimmy, W. 2010. Teh. Wikipedia Indonesia.com (Diakses pada tanggal 10 Agustus 2018)

Komes D, Horzik DH, Belscak A, Ganik KK, dan Vulic I. 2010. Green tea preparation and its influence on the content of bioactive compounds. Food Research International. 43 : 167-176

Kusbiantoro,D.Y.Purwaningrum. 2018. Pemanfaatan kandungan metabolit sekunder pada tanaman kunyit dalam mendukung peningkatan pendapatan masyarakat. Jurnal Kultivasi. Vol 17. No 1

Kusmana C, Dodi S, Nyoto S, Rinekso S. 2008. Ekologi tumbuhan pedada (Sonneratia caseolaris (L) Engler 1987) pada kawasan Muara Angke Propinsi Daerah Khusus Ibukota Jakarta. Jurnal KKMN 54(8):1-4.

Minqing T, Haofu D, Xiaoming L, Bingui W. 2009. Chemical constituents of marine medicinal mangrove plant Sonneratia caseolaris. 27(2):288-296

Rahman, R. 2016. Pemanfaatan Buah Pedada (Sonneratia caseolaris) dan Buah Naga Merah (Hylocereus polyrhizus) dalam Pembuatan Fruit Leather. Skripsi. Fakultas Pertanian. Universitas Riau. Pekanbaru.

Rismunandar dan Farry B.Paimin.2001.

Kayu Manis Budidaya dan

Pengolahan. Jakarta : Penebar

Swadaya: Jakarta.

Riset Kesehatan Dasar. 2007. Badan Penelitian dan Pengembangan Kesehatan.Jakarta: Departemen Kesehatan, Republik Indonesia.

Rudianto. 2015. Pemanfaatan buah buah pedada (Sonneratia caseolaris) dalam pembuatan dodol buah pada tingkat perbandingan tepung ketan dan buah buah pedada. Skripsi. 
Fakultas Pertanian. Universitas Riau. Pekanbaru.

Sari, Mei Ambar. 2015. Aktivitas Antioksidan Teh Daun Alpukat (Persea America Mill) Dengan Variasi Teknik dan Lama Pengeringan. UMS. Surakarta

Setiawan, E. 2016. Pemanfaatan Buah Pedada (Sonneratia caseolaris) Dalam Pembuatan Selai. Skripsi. Fakultas Pertanian. Universitas Riau. Pekanbaru

Sinaga, F,A. 2016. Stress Oksidatif Dan Status Antioksidan Pada Aktivitas Fisik Maksimal. Jurnal Generasi Kampus . Volume 9, Nomor 2

Soraya. 2007. Sehat dan Cantik Berkat Teh Hijau. Jakarta: Penebar Plus

Sulistyani, R,E. 2013. Pengaruh penambahan jahe dan kayu manis terhadap kopi mengkudu yang dihasilkan. Karya Tulis Ilmiah. Politeknik Pertanian Negeri Samarinda.

Varghese JK, Belzik N, Nisha AR, Resmi S, Silvipriya KS. 2010. Pharmacognostical and phytochemical studies of a mangrove (Sonneratia caseolaris) from Kochi of Kerala State in India. Journal of Pharmacy research 3(11):26252627.
Verma, A. Alpana, s. 2014. Optimization and Quality assessment of LowCalorie Herbal Tea Sweetened with Stevia (Stevia rebaudiana).Journal of Medical Research andDevelopment. 3(2): 134-137

Werdhasari, Asri. 2014. Peran Antioksidan Bagi Kesehatan. Jurnal Biotek Medisiana Indonesia .Vol.3.2.2014: 59-68

Winarti, C., Nurdjanah, N. (2005). Peluang Tanaman Rempah dan Obat Sebagai Sumber Pangan Fungsional. Jurnal Litbang Pertanian. 24 : 47 -55

Winarto, I.W. 2004. Khasiat dan Manfaat Kunyit . Jakarta : AgroMedia Pustaka

Wiratno, agung, S. Vonny, S, J. Faizah,H. 2017. Pemanfaatan Buah Pedada (Sonneratia caseolaris) dalam pembuatan minuman instan. JOM FAPERTA UR. Vol 4. No 1

Yulia, A., Suparmo, Harmayani, E. 2015. Pengaruh minuman dari Ekstrak KayuManis - Madu Terhadap Kadar Gula Darah Tikus Terinduksi Aloksan. Jurnal penelitian Universitas Jambi Seri Sains. 17(1) : 76-83 